\title{
Perancangan dan Fabrikasi Mesin Pengolah Ubi Kayu untuk Produksi Makanan Ringan Lanting Kapasitas 40 kg/jam
}

\author{
Satriawan Dini Hariyanto*, Rikson Gilbert Papasi, Ghoyali Rizyal Munthohani, Irtifa \\ Tashinudin Lanekri, I Putu Sastika \\ Jurusan Teknik Mesin, Fakultas Teknologi Industri, Institut Sains \& Teknologi AKPRIND \\ Jl. Kalisahak No.28, Klitren, Gondokusuman, Kota Yogyakarta, Daerah Istimewa Yogyakarta \\ Penulis Korespondensi: satriawan@akprind.ac.id
}

Histori artikel: diserahkan 20 Oktober 2020, direviu 22 Oktober 2020, direvisi 27 Oktober 2020

\begin{abstract}
The development of the food processing industry carried out by MSMEs in Indonesia is still largely dominated by traditional processing systems. A problem occurred in terms of the need for much labor to require higher production processes. An example of MSMEs that currently in promising development is the cassava chips snack industry. Many employees involved in the cassava chips production process, long production process, and the cassava chips (lanting) produced is a lack of uniformity. This study aims to design and fabricate a lanting extruder machine with a capacity of $40 \mathrm{~kg} / \mathrm{hour}$ with a 0.5 HP electric motor. The FEA simulation results with the loading of $490.5 \mathrm{~N}$ using Autodesk Inventor 2020 software showed a maximum Von Misses stress of $17.68 \mathrm{MPa}$, a displacement of $0.04 \mathrm{~mm}$, and a safety factor of 11.7.
\end{abstract}

Keywords: Lanting extruder machine, FEA, food processing, MSMEs, cassava chips.

DOI: https://doi.org/10.18196/jqt.020121

Web: https://journal.umy.ac.id/index.php/qt/article/view/10050

\section{PENDAHULUAN}

Pemanfaatan ubi kayu (singkong) sebagai bahan baku makanan telah banyak dilakukan di Indonesia. Ubi kayu banyak dimanfaatkan oleh masyarakat sebagai bahan pangan pokok pengganti beras. Selain itu, ubi kayu juga banyak dimanfaatkan sebagai bahan utama untuk membuat makanan ringan (snack). Pengolahan ubi kayu sebagai bahan makanan ringan salah satunya adalah menjadikannya sebagai bahan baku makanan ringan lanting. Lanting merupakan makanan ringan khas dari kecamatan Kuwarasan kabupaten Kebumen, Jawa Tengah. Geometri lanting berbentuk angka delapan atau lingkaran kecil seperti cincin. Kegiatan pengolahan singkong menjadi produk jadi berupa makanan ringan lanting didominasi oleh UMKM (Usaha Mikro Kecil dan Menengah). Perkembangan UMKM di Indonesia mengalami peningkatan dari tahun ke tahun. Berdasarkan penelitian yang dilakukan oleh Gunawan et al. (2017) pada tahun 2012 UMKM mampu menyerap tenaga kerja sebanyak 107.657.509 orang tenaga kerja atau 97,16 persen, sedangkan usaha besar sebanyak 3.150.645 orang tenaga kerja atau 2,84 persen. Dari sisi jumlah unit usaha, pada tahun 2012 jumlah UMKM yang berdiri sebanyak 56.534.592 unit atau 99,99 persen, sedangkan usaha besar hanya 4.968 unit atau 0,01 persen. Selain itu Indonesia merupakan negara dengan produksi ubi kayu (singkong) terbesar ke empat di dunia setelah Nigeria (34 juta ton), Brazil (24,6 juta ton) dan Thailand (19,2 juta ton). Produksi singkong Indonesia berkontribusi sebesar 9,7\% dari total produksi singkong dunia yang mencapai 175,25 juta ton (Saleh, 2014). Besarnya potensi sumber bahan baku ubi kayu tersebut masih terkendala halhal teknis dalam proses pengolahan ubi kayu menjadi produk jadi, adapun kendala yang dialami para pelaku UMKM antara lain : rendahnya tingkat penggunaan varietas bibit unggul dan penerapan teknologi produksi yang masih kurang (Saleh, 2014). Pada penelitian ini proses perancangan dan fabrikasi mesin pengolah ubi kayu (singkong) dilakukan untuk mencetak produk makanan ringan lanting dengan kapasitas produksi $40 \mathrm{~kg} / \mathrm{jam}$. Analisis metode elemen hingga dan metode perancangan elemen mesin dilakukan untuk menjamin bahwa mesin yang diproduksi memenuhi aspek keamanan dan kehandalan dalam pengoperasian. 
Ardhyka (2018), merancang mesin pencetak lanting ini mampu mencetak dua cincin dengan pisau pemotong, kapasitas $45 \mathrm{~kg} / \mathrm{jam}$ mesin daya penggerak motor listrik $1 \mathrm{HP}$ hp $(0,746$ $\mathrm{kw}$ ), dengan putran $1420 \mathrm{rpm}$. Diameter poros motor penggerak berukuran $13 \mathrm{~mm}$, diameter poros tengah berukuran $22 \mathrm{~mm}$ dan diameter poros penggiling berukuran $33 \mathrm{~mm}$. Penggerak memakai sabuk $\mathrm{V}$ tipe A berjumlah 2 buah. Untuk jarak antar poros $599 \mathrm{~mm}$ dengan rangka bahan besi siku $40 \mathrm{~mm} \mathrm{x} 40 \mathrm{~mm} \mathrm{x}$ $3 \mathrm{~mm}$.

Pramono (2012), merancang mesin penyulir daging untuk pembuatan abon dengan penggerak motor listrik 1 HP yang menggerakan puli pada motor kemudian dari puli di transmisikan menggunakan sabuk ke poros penyuir, sehingga poros penyuir berputar dan terjadi proses penyuiran daging. Hasil dari perancangan didapatakan desain mesin penyuir daging dengan spesifikasi panjang $600 \mathrm{~mm}$, lebar $750 \mathrm{~mm}$, tinggi $875 \mathrm{~mm}$ dan mesin penyuir daging yang memiliki kapasitas 25 $\mathrm{kg} / \mathrm{jam}$.

Mubarok (2012), merancang alat perajang singkong untuk pembuatan kripik singkong dengan penggerak motor listrik yang di transmisikan oleh puli dan sabuk untuk menggerakan poros yang tersambung oleh pisau pemotong. Hasil dari perancangan alat perajang singkong ini adalah kerangka memiliki panjang $300 \mathrm{~mm}$ dan lebar $500 \mathrm{~mm}$, yang mampu memotong singkong dengan ketebalan 1-2 mm. dengan kapasitas 30 $\mathrm{kg} / \mathrm{jam}$.

\section{MATERIAL DAN METODE}

\section{Material}

Desain mesin pencetak lanting ditunjukkan pada Gambar 1. Komponen yang digunakan untuk proses fabrikasi terbagi menjadi dua jenis, yaitu komponen yang dibeli dan komponen yang dibuat. Adapun keputusan daftar pembelian ataupun pembuatan komponen (make or buy) yang menyusun mesin ditunjukkan oleh Tabel 1.

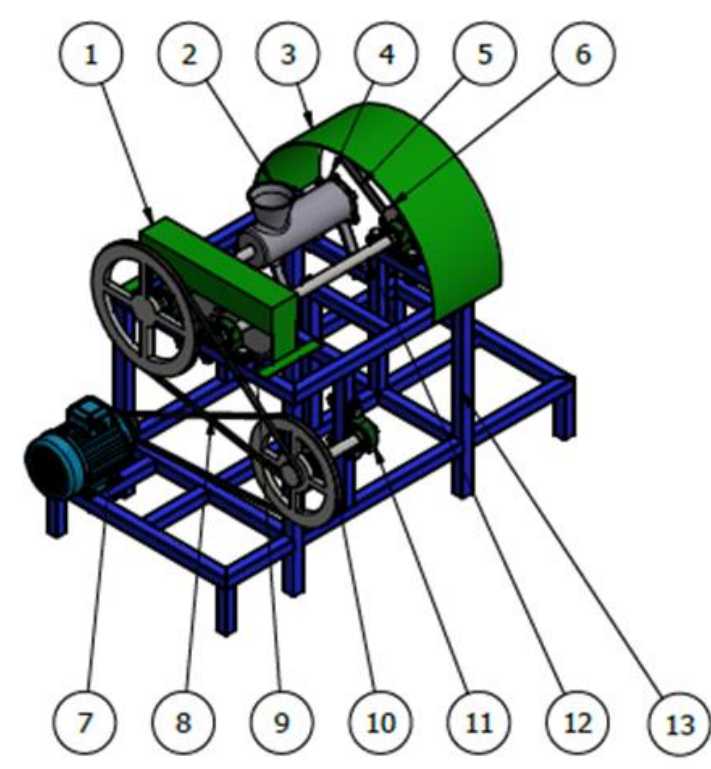

GAMBAR 1. Desain 3D mesin pencetak lanting

Terdapat kurang lebih tiga belas komponen utama yang terdapat pada mesin pencetak lanting. Spesifikasi komponen-komponen yang terdapat pada mesin pencetak lanting secara detail disajikan pada Tabel 2 .

TABEL 1. Make or buy decision making

\begin{tabular}{|c|c|c|c|}
\hline \multirow{2}{*}{ No. } & \multirow{2}{*}{$\begin{array}{c}\text { Nama } \\
\text { Komponen }\end{array}$} & \multicolumn{2}{|c|}{ Membeli/Membuat } \\
\hline & & Membeli & Membuat \\
\hline 1 & Cover Gear & & $\sqrt{ }$ \\
\hline 2 & Penggiling & $\sqrt{ }$ & \\
\hline 3 & Cover Pisau & & $\sqrt{ }$ \\
\hline 4 & Cetakan Lanting & & $\sqrt{ }$ \\
\hline 5 & Pisau Pemotong & & $\sqrt{ }$ \\
\hline 6 & Dudukan Pisau & & $\sqrt{ }$ \\
\hline 7 & Motor Listrik & $\sqrt{ }$ & \\
\hline 8 & $V$-belt & $\sqrt{ }$ & \\
\hline 9 & Gear & $\sqrt{ }$ & \\
\hline 10 & Pulley & $\sqrt{ }$ & \\
\hline 11 & Pillow Block & $\sqrt{ }$ & \\
\hline 12 & Poros & $\sqrt{ }$ & \\
\hline 13 & Rangka Utama & & $\sqrt{ }$ \\
\hline
\end{tabular}


TABEL 2. Komponen penyusun mesin

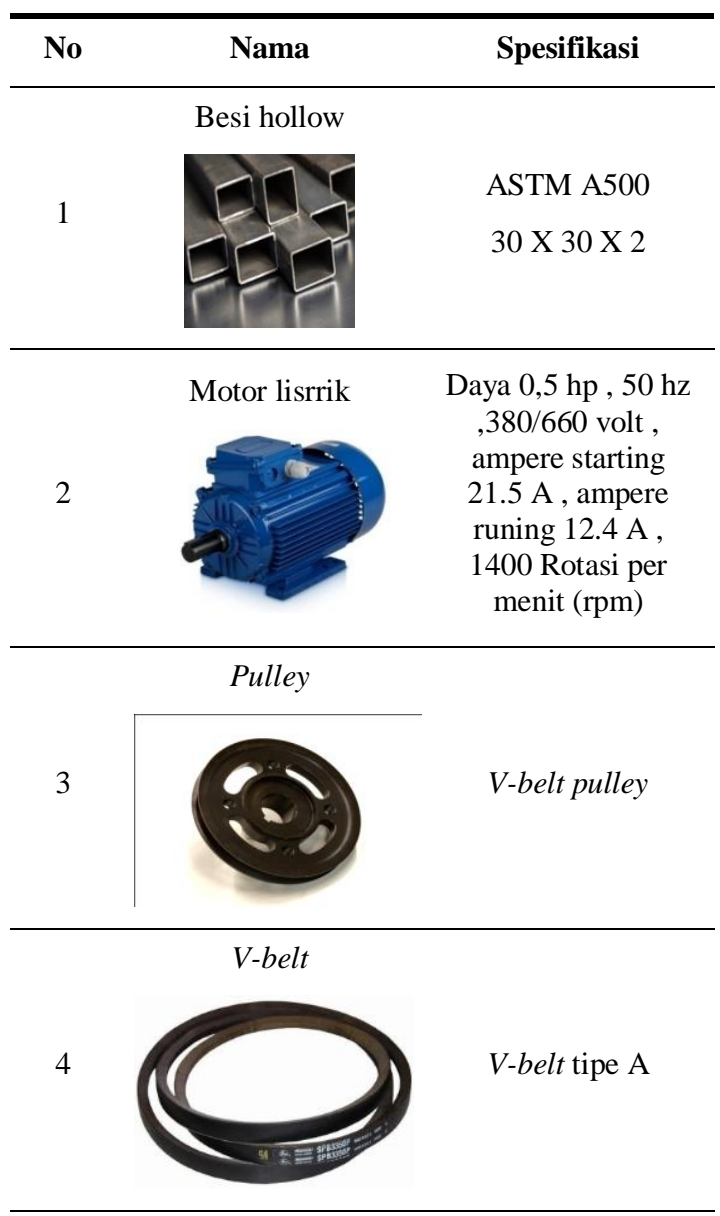

Poros

5

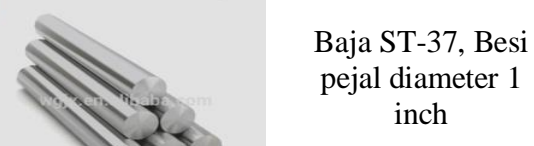

6

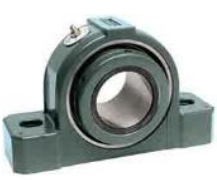

PillowBlock

Bearing

Gear

7

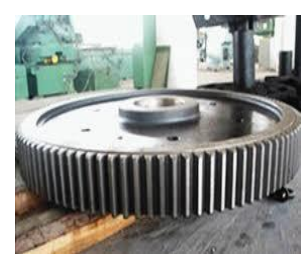

Diameter $14 \mathrm{~cm}$
Pisau pemotong

8

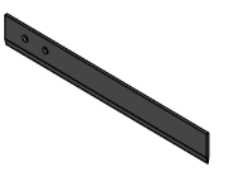

Stainless steel 304

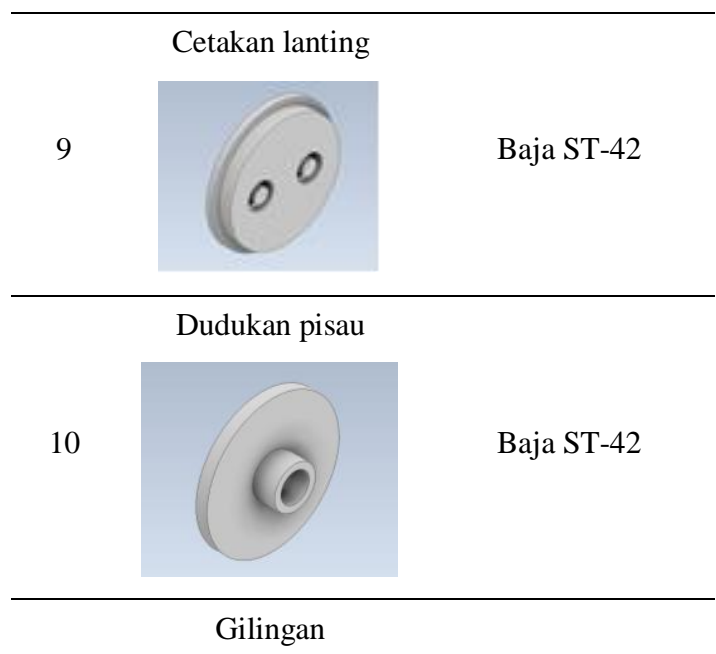

11

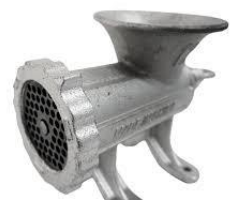

Besi cor

Cover gear

12

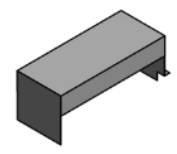

Baja ST-42

Cover pisau

13

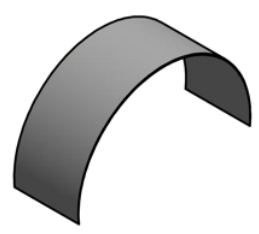

Baja ST-42 


\section{Metode}

Urutan metode perancangan dan fabrikasi mesin pencetak lantinf pada penelitian ini ditunjukkan pada Gambar 2.

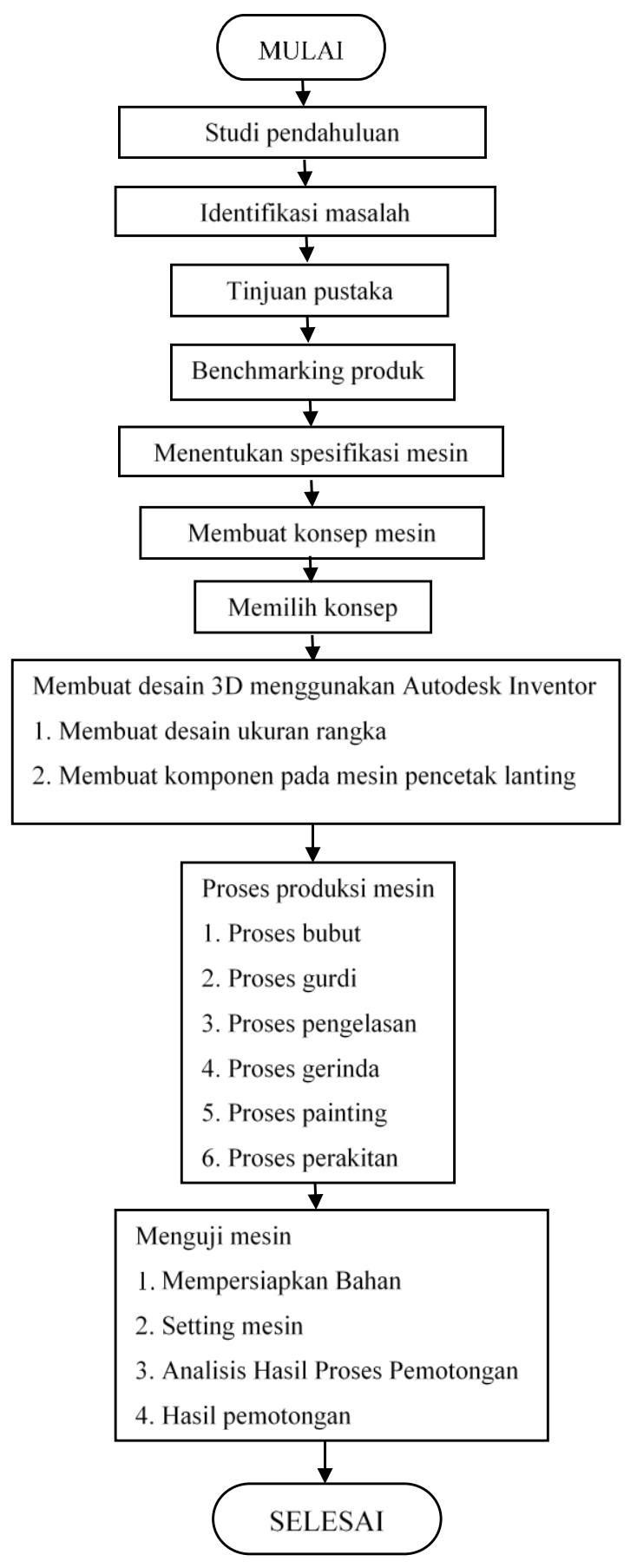

GAMBAR 2. Diagram alir perancangan mesin

\section{Simulasi FEA (Finite Element Analysis)}

Finite element analysis dilaksanakan pada tahap setelah diperoleh gambar 3D dari konsep produk yang akan difabrikasi. Adapun parameter pembebanan yang diatur dalam simulasi FEA menggunakan software Autodesk Inventor 2020 dengan menggunakan pembebanan sebesar 490,5 N. Simulasi FEA dilakukan untuk mengetahui besar tegangan von Misses maksimum yang terjadi pada struktur rangka yang ditunjukkan pada Gambar 3 , nilai displacement yang ditunjukkan pada Gambar 4, dan safety factor yang ditunjukkan pada Gambar 5.

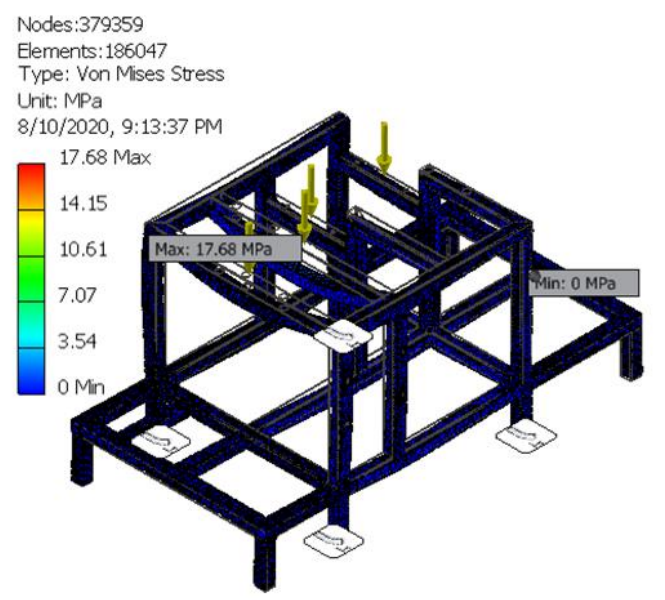

GAMBAR 3. Simulasi FEA untuk von Misses stress di Autodesk Inventor

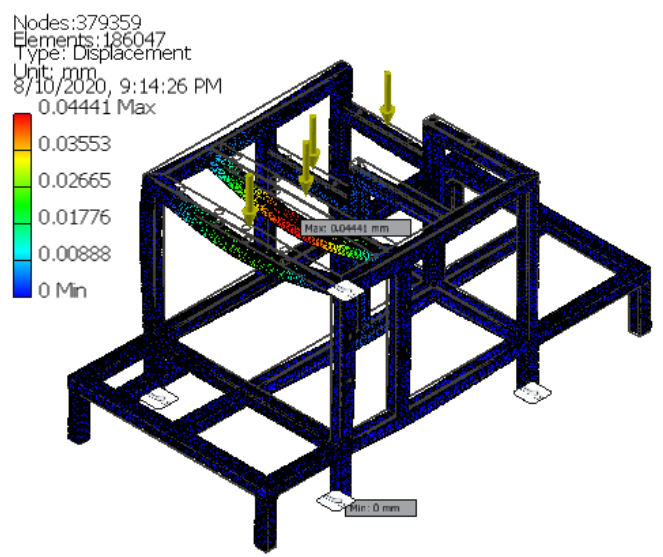

GAMBAR 4. Simulasi FEA untuk displacement di Autodesk Inventor 
- Diameter pulley digerakan (D4) $=300 \mathrm{~mm}$

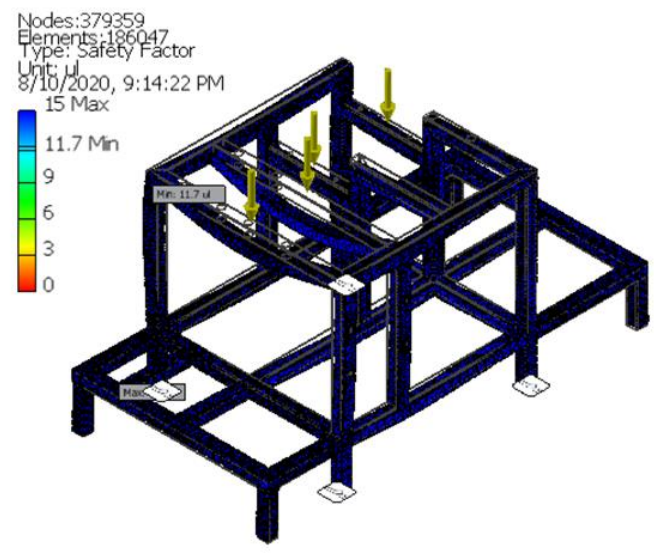

GAMBAR 5. Simulasi FEA untuk safety factor di Autodesk Inventor

\section{Kalkulasi elemen mesin}

Perhitungan Poros:

Diketahui,

- Daya motor $(P)=0,5 \mathrm{Hp}=0,37 \mathrm{~kW}$

- $f_{c}$ ( faktor koreksi) $=1,4$

- Putaran motor listrik $(n)=1400 \mathrm{rpm}$

Menentukan daya rencana poros $\left(P_{d}\right)$ (Sularso, hal 7)

$$
\begin{aligned}
P_{d} & =f_{c} \cdot \mathrm{P} \\
& =1,4 \cdot 0,37 \mathrm{~kW} \\
& =0,518 \mathrm{~kW}
\end{aligned}
$$

Momen puntir (T):

Daya rencana $\left(P_{d}=0,518 \mathrm{~kW}\right)$ maka momen puntir dapat dihitung dengan persamaan yaitu sebagai berikut (Sularso, hal 7) :

$$
\begin{aligned}
\mathrm{T} & =9,74 \times 10^{5} \cdot \frac{P_{d d}}{n} \\
& =9,74 \times 10^{5} \cdot \frac{0.518 \mathrm{~kW}}{1400} \\
& =360,38 \mathrm{~kg} \cdot \mathrm{mm}
\end{aligned}
$$

Perhitungan Transmisi dan Pemilihan Tipe Sabuk-V

Menghitung kecepatan (n)

Diketahui:

- Daya motor $(\mathrm{P})=0,5 \mathrm{Hp}=0,373 \mathrm{Kw}$

- $\operatorname{Putaran} \operatorname{mesin}(\mathrm{n})=1400 \mathrm{Rpm}$

- Diameter pulley penggerak (D1) $=60 \mathrm{~mm}$

- Diameter pulley digerakan (D2) $=200 \mathrm{~mm}$

- Diameter pulley digerakan $(\mathrm{D} 3)=80 \mathrm{~mm}$

$$
\begin{aligned}
& \frac{\mathrm{N} 1}{N 2}=\frac{D 2}{D 1} \\
& \frac{1400}{N 2}=\frac{20}{6} \\
& \mathrm{~N} 2=\frac{1400.6}{20}=420 \mathrm{Rpm} \\
& \frac{\mathrm{N} 3}{N 4}=\frac{D 4}{D 3} \\
& \frac{420}{N 2}=\frac{30}{8} \\
& \mathrm{~N} 4=\frac{420.8}{30}=112 \mathrm{rpm}
\end{aligned}
$$

Jadi kecepatan putaran motor 1400 Rpm direduksi menggunakan 2 buah pulley menjadi 112 Rpm.

Penampang sabuk-V:

Diketahui,

- Daya motor $(P)=0,5 \mathrm{Hp}=0,37 \mathrm{~kW}$

- $f_{c}$ ( faktor koreksi) $=1,4$

- Putaran motor listrik $(n)=1400 \mathrm{rpm}$

- Daya rencana poros $\left(P_{d}\right)=0,518 \mathrm{~kW}$

Jadi daya yang ditransmisikan adalah 0,518 $\mathrm{kW}$ dengan putaran $1400 \mathrm{rpm}$. Maka, data diatas dimasukan kedalam diagram pemilihan sabuk dan didapatkan jenis penampang sabuk Tipe A menurut diagram pada Gambar 6.

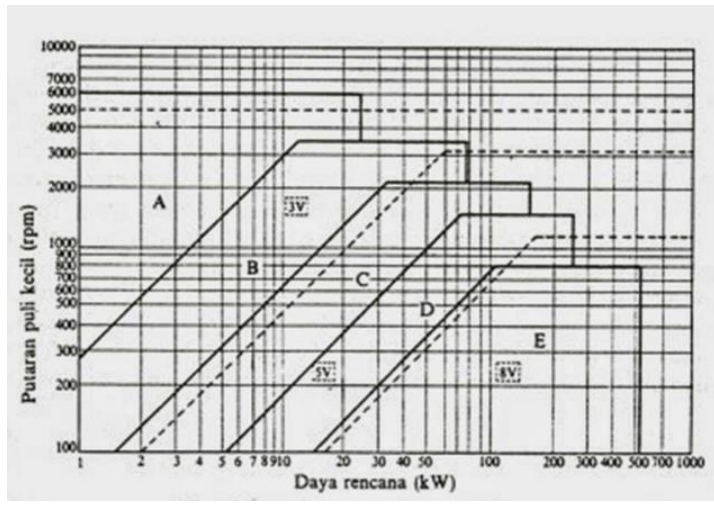

GAMBAR 6. Diagram pemilihan sabuk-V (Sumber: Sularso, 2002:164) 


\section{Analisan Pemilihan Bahan Pisau dan Cetakan}

Analisa bahan pisau pemotong menggunakan metode digital logic ditunjukkan pada Tabel 3.

TABEL 3. Nilai a (alfa) pada pisau pemotong

\begin{tabular}{|c|c|c|c|c|c|c|c|c|c|c|c|c|c|}
\hline $\begin{array}{l}\text { Sifat } \\
\text { Bahan } \\
\end{array}$ & No & $1 / 2$ & $1 / 3$ & $1 / 4$ & $1 / 5$ & $2 / 3$ & $2 / 4$ & $2 / 5$ & $3 / 4$ & $3 / 5$ & $4 / 5$ & $\mathrm{n}$ & $\alpha$ \\
\hline$\stackrel{\overrightarrow{\widetilde{\sigma}}}{\vec{\Delta}}$ & 1 & 1 & 0 & 0 & 1 & & & & & & & 2 & 0,2 \\
\hline $\begin{array}{l}\text { 喆 } \\
\text { 意 }\end{array}$ & 2 & 0 & & & & 1 & 1 & 0 & & & & 2 & 0,2 \\
\hline 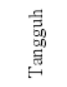 & 3 & & 1 & & & 0 & & & 1 & 0 & & 2 & 0,2 \\
\hline 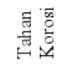 & 4 & & & 1 & & & 0 & & 0 & & 1 & 2 & 0,2 \\
\hline \multirow[t]{2}{*}{ 氞 } & 5 & & & & 0 & & & 1 & & 1 & 0 & 2 & 0,2 \\
\hline & & & & & & & & & & & & 10 & 1 \\
\hline
\end{tabular}

$N=\frac{n(n-1)}{2}=\frac{5(5-1)}{2}=10$

$\beta$ Bahan pada pisau pemotong ditunjukkan pada Tabel 4 berikut:

TABEL 4. Nilai bahan pada pisau pemotong (Sumber www.matweb.com)

\begin{tabular}{llllll}
\hline Bahan & $\begin{array}{l}\text { Kuat } \\
(\mathrm{Max}) \\
\mathrm{MPa}\end{array}$ & $\begin{array}{l}\text { Density } \\
(\mathrm{Min}) \\
\mathrm{Mg} / \mathrm{m}^{3}\end{array}$ & $\begin{array}{l}\text { Tangguh } \\
(\mathrm{Max}) \\
\mathrm{MPa} / \mathrm{m}\end{array}$ & $\begin{array}{l}\text { Laju } \\
\text { Korosi } \\
(\mathrm{min}) \\
\mathrm{mm}^{3} / \text { year }\end{array}$ & $\begin{array}{l}\text { Murah } \\
(\mathrm{min}) \\
\mathrm{Rp} / \mathrm{kg} \\
* 2 \mathrm{rb}\end{array}$ \\
\hline $\mathrm{Al}$ & 128 & 2,5 & 28 & 100 & 28 \\
\hline Zink & 235 & 4,95 & 18 & 120 & 23 \\
\hline $\begin{array}{l}\mathrm{SS} \\
304\end{array}$ & 480 & 7,6 & 128 & 40 & 56 \\
\hline
\end{tabular}

Jika sifat tinggi

$\beta=\frac{\text { nilai bahan yang ditinjau }}{\text { nilai bahan tertinggi }} \times 100 \%$

Jika sifat rendah

$\beta=\frac{\text { nilai bahan terendah }}{\text { nilai bahan yang ditinjau }} \times 100 \%$
TABEL 5. Nilai $\beta$ pada pisau pemotong

\begin{tabular}{llllll}
\hline Bahan & $\begin{array}{l}\text { Kuat } \\
(\mathrm{Max}) \\
\mathrm{MPa}\end{array}$ & $\begin{array}{l}\text { Density } \\
(\mathrm{Min}) \\
\mathrm{Mg} / \mathrm{m}^{3}\end{array}$ & $\begin{array}{l}\text { Tangguh } \\
(\mathrm{Max}) \\
\mathrm{MPa} / \mathrm{m}\end{array}$ & $\begin{array}{l}\text { Laju } \\
\text { Korosi } \\
(\mathrm{min}) \\
\mathrm{mm}^{3} / \text { year }\end{array}$ & $\begin{array}{l}\text { Murah } \\
(\mathrm{min}) \\
\mathrm{Rp} / \mathrm{kg} \\
* 2 \mathrm{rb}\end{array}$ \\
\hline $\mathrm{Al}$ & 26,67 & 100 & 21,87 & 40 & 82,14 \\
\hline Zink & 48,95 & 50,5 & 14,06 & 33,34 & 100 \\
\hline $\begin{array}{l}\mathrm{SS} \\
304\end{array}$ & 100 & 32,89 & 100 & 100 & 41,07 \\
\hline
\end{tabular}

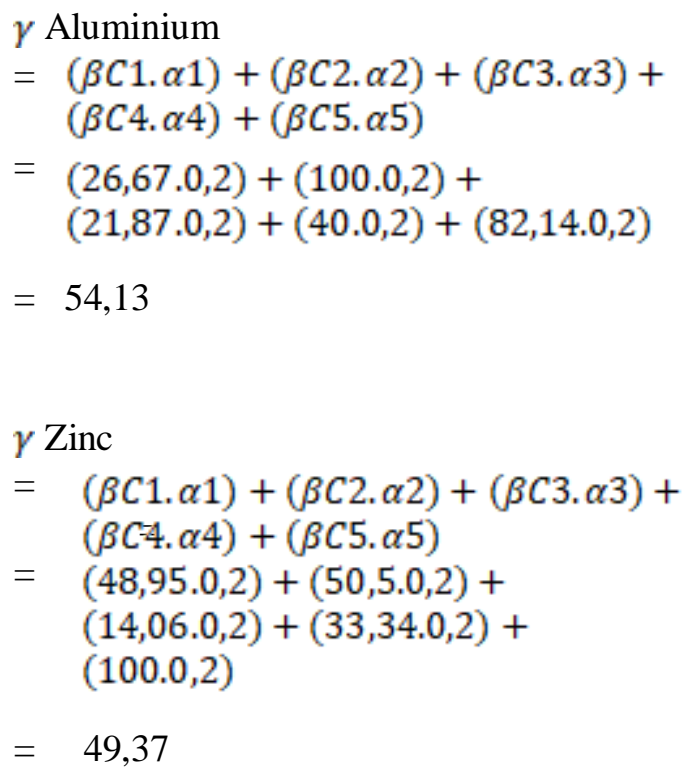

$\gamma$ Stainless Steel 304

$=(\beta C 1, \alpha 1)+(\beta C 2, \alpha 2)+(\beta C 3, \alpha 3)+$ $(\beta C 4, \alpha 4)+(\beta C 5, \alpha 5)$

$=(100.0,2)+(32,89.0,2)+$ $(100.0,2)+(100.0,2)+41,07.0,2)$

$=74,79$

Jadi bahan yang digunakan untuk pisau pemotong adalah Stainless Steel 304 dengan nilai $\gamma$ sebesar 74,79

Analisa bahan cetakan lanting menggunakan metode digital logic ditunjukkan pada Tabel 6 berikut: 
TABEL 6. Nilai $\alpha$ (alfa) pada cetakan lanting

\begin{tabular}{|c|c|c|c|c|c|c|c|c|c|c|c|c|c|}
\hline $\begin{array}{l}\text { Sifat } \\
\text { Bahan }\end{array}$ & No & $1 / 2$ & $1 / 3$ & $1 / 4$ & $1 / 5$ & $2 / 3$ & $2 / 4$ & $2 / 5$ & $3 / 4$ & $3 / 5$ & $4 / 5$ & $\mathrm{n}$ & $\alpha$ \\
\hline $\begin{array}{l}\overrightarrow{\mathrm{E}} \\
\vec{\Delta}\end{array}$ & 1 & 1 & 1 & 0 & 1 & & & & & & & 3 & 0,3 \\
\hline 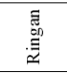 & 2 & 0 & & & & 1 & 1 & 0 & & & & 2 & 0,2 \\
\hline 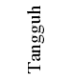 & 3 & & 0 & & & 0 & & & 1 & 0 & & 1 & 0,1 \\
\hline 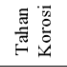 & 4 & & & 1 & & & 0 & & 0 & & 0 & 1 & 0,1 \\
\hline 嗃 & 5 & & & & 0 & & & 1 & & 1 & 1 & 3 & 0,3 \\
\hline & & & & & & & & & & & & 10 & 1 \\
\hline
\end{tabular}

$N=\frac{n(n-1)}{2}=\frac{5(5-1)}{2}=10$

$\beta$ Bahan pada cetakan lanting ditunjukkan pada Tabel 7 berikut.

TABEL 7. Nilai bahan pada cetakan lanting (Sumber www.matweb.com)

\begin{tabular}{|c|c|c|c|c|c|}
\hline Bahan & $\begin{array}{l}\text { Kuat } \\
\text { (Max) } \\
\text { MPa }\end{array}$ & $\begin{array}{l}\text { Density } \\
\text { (Min) } \\
\mathrm{Mg} / \mathrm{m}^{3}\end{array}$ & $\begin{array}{l}\text { Tangguh } \\
\text { (Max) } \\
\mathrm{MPa} / \mathrm{m}\end{array}$ & $\begin{array}{l}\text { Laju } \\
\text { Korosi } \\
(\mathrm{min}) \\
\mathrm{mm}^{3} / \text { year }\end{array}$ & $\begin{array}{l}\text { Murah } \\
\text { (min) } \\
\mathrm{Rp} / \mathrm{kg} \\
* 2 \mathrm{rb}\end{array}$ \\
\hline $\mathrm{Al}$ & 128 & 2,5 & 28 & 100 & 28 \\
\hline $\begin{array}{l}\text { Baja } \\
\text { ST } 42\end{array}$ & 490 & 5,5 & 112 & 119 & 25 \\
\hline SS & 480 & 7,6 & 128 & 40 & 56 \\
\hline
\end{tabular}

Jika sifat tinggi

$\beta=\frac{\text { nilai bahan yang ditinjau }}{\text { nilai bahan tertinggi }} \times 100 \%$

Jika sifat rendah

$\beta=\frac{\text { nilai bahan terendah }}{\text { nilai bahan yang ditinjau }} \times 100 \%$

TABEL 8. Nilai $\beta$ pada cetakan lanting

\begin{tabular}{|c|c|c|c|c|c|}
\hline Bahan & $\begin{array}{l}\text { Kuat } \\
\text { (Max) } \\
\mathrm{MPa}\end{array}$ & $\begin{array}{l}\text { Density } \\
\text { (Min) } \\
\mathrm{Mg} / \mathrm{m}^{3}\end{array}$ & $\begin{array}{l}\text { Tangguh } \\
\text { (Max) } \\
\mathrm{MPa} / \mathrm{m}\end{array}$ & $\begin{array}{l}\text { Laju } \\
\text { Korosi } \\
(\mathrm{min}) \\
\mathrm{mm}^{3} / \text { year }\end{array}$ & $\begin{array}{l}\text { Murah } \\
\text { (min) } \\
\mathrm{Rp} / \mathrm{kg} \\
* 2 \mathrm{rb}\end{array}$ \\
\hline $\mathrm{Al}$ & 26,12 & 100 & 21,87 & 40 & 89,28 \\
\hline $\begin{array}{l}\text { Baja } \\
\text { ST } 42\end{array}$ & 100 & 45,45 & 87,5 & 33,61 & 100 \\
\hline SS & 97,95 & 32,89 & 100 & 100 & 44,64 \\
\hline
\end{tabular}

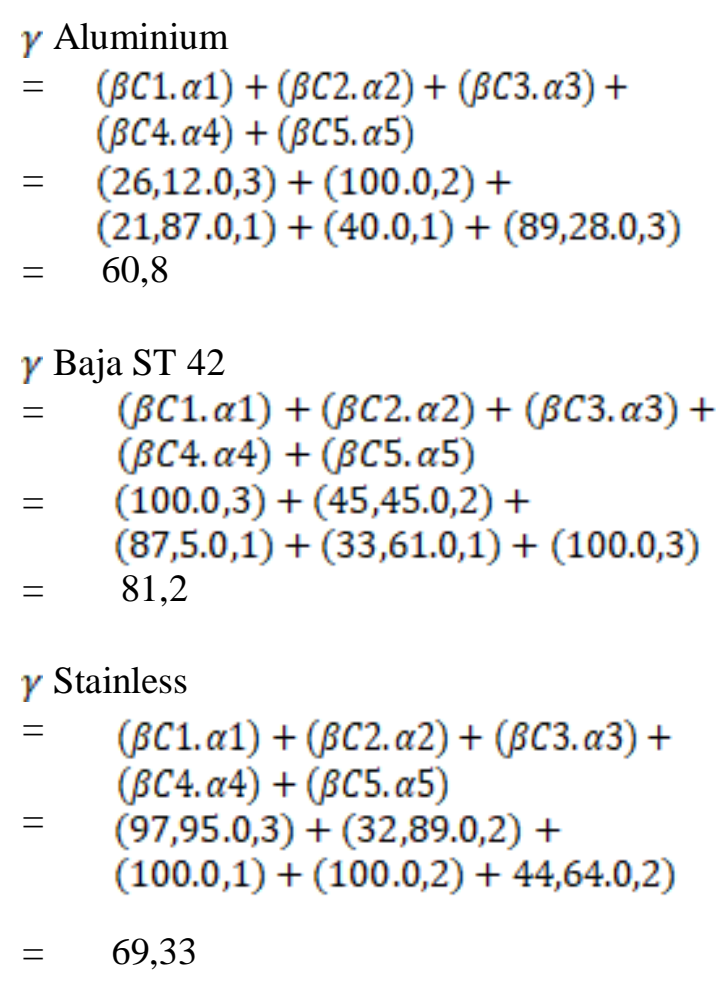

Jadi bahan yang digunakan untuk cetakan lanting adalah Baja ST 42 dengan nilai $\gamma$ sebesar 81,2

\section{HASIL DAN PEMBAHASAN}

Von Misses Stress

Tegangan maksimum Von Misses yang dialami oleh struktur model 3D yang dibebani gaya 490,5 $\mathrm{N}$ yang disimulasikan menggunakan Autodesk Inventor adalah sebesar 17,68 Mpa seperti ditunjukkan pada Gambar 2.2b. Hal ini menunjukkan tegangan yang terjadi berada di bawah nilai tegangan luluh (yield strength) material rangka yang bernilai 268,8 MPa (Purnomo et al., 2014)

\section{Displacement}

Hasil simulasi menunjukkan bahwa total displacement terbesar ada pada rangka sebesar $0,04441 \mathrm{~mm}$ seperti ditunjukkan pada Gambar 4.

\section{Safety factor}

Hasil simulasi menunjukkan safety factor maksimal ada pada rangka sebesar 15 , dan safety factor terkecil sebesar 11,7 seperti ditunjukkan pada Gambar 5. 
Hasil Pengujian Mesin

Pengujian performa mesin (Gambar 7) untuk mencetak lanting dilakukan sebanyak tiga kali pengujian dengan hasil seperti ditunjukkan pada Tabel 9. Produk hasil olahan ditunjukkan pada Gambar 8.

TABEL 9. Hasil pengujian mesin

\begin{tabular}{lll}
\hline No & $\begin{array}{c}\text { Jumlah adonan } \\
\text { yang dimasukan }\end{array}$ & $\begin{array}{c}\text { Waktu yang } \\
\text { dibutuhkan untuk } \\
\text { mencetak lanting }\end{array}$ \\
\hline 1 & $3 \mathrm{~kg}$ & 4,4 menit \\
\hline 2 & $2 \mathrm{~kg}$ & 3,4 menit \\
\hline 3 & $4 \mathrm{~kg}$ & 5,2 menit \\
\hline $\begin{array}{l}\text { Rata- } \\
\text { rata }\end{array}$ & $3 \mathrm{~kg}$ & $\begin{array}{l}4,3 \text { menit atau } 258 \\
\text { detik }\end{array}$ \\
\hline
\end{tabular}

Nilai kapasitas rata-rata produksi lanting (Q) pada saat percobaan :

$$
\begin{aligned}
\mathrm{Q} & =\frac{3 \mathrm{~kg}}{258} \cdot 3600 \mathrm{~s} / \mathrm{jam} \\
& =41,8 \mathrm{Kg} / \mathrm{jam}
\end{aligned}
$$

Kapasitas $41,8 \mathrm{~kg} / \mathrm{jam}$ pada saat percobaan sesuai dengan kapasitas perencanaan sebesar $40 \mathrm{~kg} / \mathrm{jam}$.

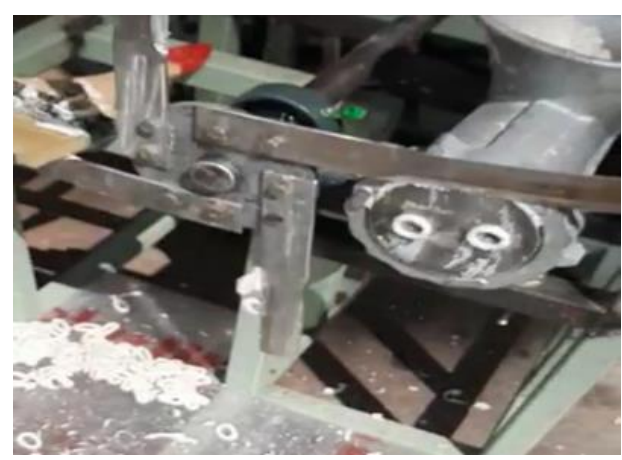

GAMBAR 7. Pengujian performa mesin pencetak lanting

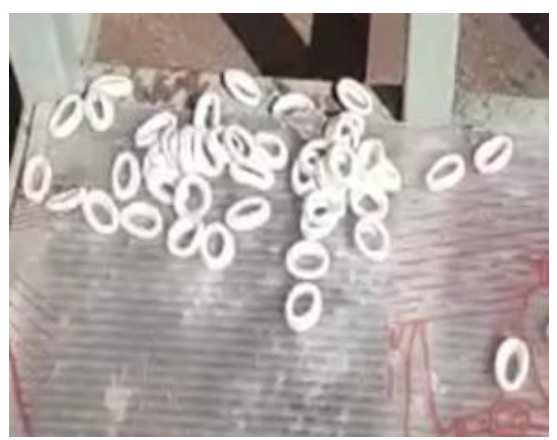

GAMBAR 8. Hasil produk lanting

\section{KESIMPULAN}

Mesin pengolah umbi ketela pohon berupa mesin pencetak lanting telah berhasil dirancang dan difabrikasi. Analisis FEA pada komponen rangka berbahan ASTM A500 menggunakan software Autodesk Inventor 2020 menunjukkan tegangan von Misses yang timbul pada rangka dengan pembebanan 490,5 $\mathrm{N}$ sebesar 17,68 MPa. Nilai tegangan ini lebih kecil dari yield strength yang dimiliki oleh material ASTM A500 yang bernilai 268,8 $\mathrm{MPa}$. Selain itu, nilai displacement yang timbul dari hasil simulasi menunjukkan nilai $0,044 \mathrm{~mm}$ dan safety factor rata-rata sebesar 13, sehingga dari sisi tegangan, displacement, dan safety factor yang bekerja pada rangka dapat disimpulkan struktur rangka mesin pencetak lanting yang dirancang aman. Berdasarkan hasil pengujian, mesin pencetak lanting yang difabrikasi menunjukkan kapasitas produksi rata-rata $41,8 \mathrm{~kg} / \mathrm{jam}$, nilai ini telah memenuhi syarat kapasitas awal pada perancangan yaitu sebesar $40 \mathrm{~kg} / \mathrm{jam}$.

\section{UCAPAN TERIMA KASIH}

Terima kasih penulis haturkan kepada IST AKPRIND yang telah membantu menyediakan fasilitas laboratorium sehingga penelitian ini dapat terlaksana dengan lancar.

\section{DAFTAR PUSTAKA}

Gunawan, R. S., Kadarwati, N., \& Sukiman, S. 2017. Analisis Perilaku Produsen UMKM Lanting Kuning dalam Pemenuhan Kebutuhan Hidup Layak di Kecamatan Sumpiuh Kabupaten Banyumas. Prosiding, 7(1).

Mubarok. 2012. Pembuatan Mesin Perajang Singkong. Diakses tanggal 2 Oktober 2020 dari http://tugasakhir-tm(mesinperajangsingkong)adenrudal0.html

Pranomo, G. 2012. Perancangan Perancangan Mesin Penyuir Daging Untuk Bahan Baku Abon. Skripsi, tidak dipublikasikan. Universitas Negri Yogyakarta.

Purnomo, A., Burhanuddin, Y., \& Harun, S. 2014. Perancangan Dan Pembuatan 
Struktur Mekanik Sistem Inspeksi Visi. Jurnal Ilmiah Teknik Mesin, 2(1).

Saleh, N., \& Widodo, Y. 2014. Profil dan peluang pengembangan ubi kayu di Indonesia. Buletin Palawija, (14), hal. 69-78.

Sularso, dan Kiyokatsu Suga. 1997. Dasar Perencanaan dan Pemilihan Elemen Mesin. Jakarta: Pradnya Paramita

Yaufan Aulia Ardhyka. 2018. Perancangan Mesin Pembuat Lanting. Jurusan Teknik Mesin Fakultas Teknik Universitas Tidar. 